\title{
Model Pelaksanaan Gerakan Literasi Sekolah di Sekolah Dasar
}

\author{
Gheanurma Ekahasta Novarina ${ }^{1}$, Anang Santoso ${ }^{2}$, Furaidah $^{3}$ \\ ${ }^{1}$ Pendidikan Dasar-Universitas Negeri Malang \\ ${ }^{2}$ Pendidikan Bahasa Indonesia-Universitas Negeri Malang \\ ${ }^{3}$ Pendidikan Bahasa Inggris-Universitas Negeri Malang
}

\section{INFO ARTIKEL}

\section{Riwayat Artikel:}

Diterima: 16-05-2019

Disetujui: 11-11-2019

Kata kunci:
school literacy movement;
habituation;
development;
learning;
gerakan literasi sekolah;
pembiasaan;
pengembangan;
pembelajaran

\section{Alamat Korespondensi:}

Gheanurma Ekahasta Novarina

Pendidikan Dasar

Universitas Negeri Malang

Jalan Semarang 5 Malang

E-mail: gheanovarina18@gmail.com

\begin{abstract}
ABSTRAK
Abstract: This study describe the implementation of school literacy movement consisting of its habituation, development and learning and obstacles in SD Muhammadiyah 4 of Surabaya. Habituation stage covers literacy activities habituation, supporting facilities, creating a literacy-rich environment, and public involvement Development stage covers habits of literacy activities, literacy activities supporting program, educators and education force in literacy activities, school literacy team and professional literacy development for educator and education force. Learning stage includes the use of enrichment book, textbook selection, responding to the text activities, and facilities utilization in learning. The research findings showed that the implementation of school literacy movement ran optimally. During its implementation, there were some obstacles such as the time to conduct the literacy activities, the availability of reading materials in the class, and diminishing commitment of the teachers to run the literacy activities inside the class along with the changing policy of the literacy habituation from the headmaster.
\end{abstract}

\begin{abstract}
Abstrak: Studi ini mendeskripsikan tentang pelaksanaan gerakan literasi sekolah yang terdiri dari pembiasaan, pengembangan dan pembelajaran dan kendalanya di SD Muhammadiyah 4 Kota Surabaya. Dalam tahap pembiasaan meliputi pembiasaan kegiatan literasi, penyediaan sarana dan prasarana, pengadaan lingkungan kaya teks dan pelibatan publik. Tahap pengembangan, meliputi kebiasaan kegiatan literasi, program pendukung kegiatan literasi, partisipasi pendidik dan tenaga kependidikan dalam kegiatan literasi, tim literasi sekolah, dan pengembangan profesional literasi bagi pendidik dan tenaga kependidikan. Tahap pembelajaran, meliputi penggunaan buku pengayaan, pemilihan buku teks pembelajaran, kegiatan menanggapi teks, pemanfaatan sarana dan prasarana dalam pembelajaran. Hasil penelitian menunjukkan bahwa pelaksanaan gerakan literasi sekolah berjalan optimal, namun masih terdapat kendala dalam pelaksanaannya, seperti masalah waktu pelaksanaan kegiatan literasi, berkurangnya koleksi baca di dalam kelas, dan berkurangnya komitmen guru dalam melaksanakan kegiatan pembiasaan membaca di kelas bersamaan dengan berubahnya kebijakan dari kepala sekolah atas pentingnya pembiasaan literasi untuk siswa.
\end{abstract}

Kegiatan literasi belum mengakar dalam budaya masyarakat di Indonesia. Berdasarkan standar Internasional, minat dan kemampuan membaca siswa masih rendah. Tahun 2011, Unesco (United Nation Education Society and Cultural Organization) menemukan fakta mengenai indeks minat baca masyarakat di Indonesia sangat rendah, yakni 0,001. Artinya, hanya satu orang dari seribu penduduk yang memiliki minat baca tinggi. Sejalan dengan riset tersebut, hasil survei literasi yang mengukur kemampuan membaca kelas IV dilakukan oleh Progress in International Reading Literacy Study (PIRLS) 2015, Indonesia memperoleh skor 428 dari skor rata-rata 500 dengan singkatnya menduduki peringkat ke-64 dari 72 negara. Selain dua rilisan, lebih lanjut "Most Literate Nation in the World" pada tanggal tujuh Maret 2016, Central Connecticut State University di New Britain menyatakan bahwa peringkat minat baca Indonesia hanya lebih baik dari sebuah negara kecil Afrika, Bostwana yaitu di urutan 60 dari 61 negara. Melalui hasil ini dapat diketahui bahwa minat baca masyarakat di Indonesia masih rendah.

Badan Pengembangan dan Pembinaan Bahasa (2016) memaparkan tentang salah satu cara menaikkan indeks literasi suatu bangsa adalah melaksanakan kegiatan pembelajaran dengan membiasakan siswa Indonesia membaca sebelum kegiatan pembelajaran yang bertujuan agar siswa memiliki kebiasaan membaca dan menulis. Menumbuhkan minat membaca sejak dini 
akan mempermudah mewujudkan budaya baca dan tradisi keaksaraan pada siswa di masa depannya. Selain itu, minat baca berhubungan erat dengan keterampilan menulis. Semakin tinggi keinginan membaca dalam diri seseorang maka semakin tinggi juga kompetensi menulisnya, begitu pula sebaliknya (Lestari, 2017). Teale \& Sulzby (1986) juga menyatakan bahwa kemahiran membaca dan menulis harus dibina secara serentak dan saling bergantung antara satu sama lain tanpa turutan yang tertentu. Dengan demikian, literasi dalam diri seseorang itu muncul secara berkelanjutan yaitu tanpa prasyarat untuk mengenal huruf terlebih dahulu dan terbina secara bersepadu antar bagian keterampilan bahasa. Menulis dan membaca harus diajarkan bersamasama karena menulis dan membaca adalah proses konstruktif, berbagi pengetahuan umum, meningkatkan prestasi di kedua bidang, membina komunikasi, dan bersama-sama menghasilkan hasil yang belum dicapai baik secara tersendiri.

Menurut Tarigan (2008), salah satu faktor pendukung minat dan kemampuan baca adalah penyediaan waktu untuk membaca. Berkaitan dengan ini, bulan Juli 2015, Peraturan Menteri Pendidikan dan Kebudayaan Nomor 23 Tahun 2015 tentang Penumbuhan Budi Pekerti telah diterbitkan oleh Kementerian Pendidikan dan Kebudayaan (Kemendikbud). Gerakan Literasi Sekolah di sekolah dasar dilaksanakan dengan meninjau kondisi lapangan yang mencakup kesiapan kapasitas fisik sekolah (ketersediaan fasilitas, sarana dan prasarana literasi), kesiapan warga sekolah, dan kesiapan sistem pendukung lainnya (partisipasi publik, dukungan kelembagaan, dan perangkat kebijakan yang relevan). Kegiatan literasi tidak identik dengan ativitas membaca dan menulis saja, namun mencakup keterampilan berpikir menggunakan sumber-sumber pengetahuan dalam bentuk cetak, visual, digital dan audio. Melalui media tersebut, siswa diharapkan mampu menyimpulkan, menafsirkan dan menguraikan apa yang telah dipelajari. Pemahaman membaca tidak hanya dilihat dari post test saja, tetapi dapat dituangkan dalam bentuk karya tulis dan kegiatan komunikasi yang dikembangkan sepanjang waktu.

Gerakan Literasi Sekolah menjadi salah satu program utama Kementerian Pendidikan dan Kebudayaan yang penyebarannya mampu memberi dampak masif ke berbagai daerah di Indonesia. Bahkan beberapa daerah tidak ragu menyatakan sebagai kota literasi. Bertepatan dengan Hari Pendidikan Nasional, pada tanggal 2 Mei 2014, Walikota Surabaya telah menobatkan kota Surabaya menjadi Kota Literasi yang bertujuan menjadikan masyarakat memiliki kegemaraan membaca dan menulis yang setara dengan bangsa maju di dunia. Mengingat perspektif Gerakan Literasi Sekolah, Sutrianto, dkk. (2016) mengungkapkan pentingnya pelibatan publik untuk berkolaborasi dan keterlibatan yang aktif untuk menyukseskan ekosistem sekolah yang literat. Sekolah dikatakan sebuah organisasi yang literat jika sekolah mampu menghasilkan lingkungan yang menyenangkan dan ramah anak dimana semua warganya menunjukkan empati dan semangat untuk mencintai pengetahuan serta berkontribusi kepada lingkungan sosialnya.

Nasser (2013) melaporkan hasil riset yang bertujuan untuk mengevaluasi program ekstrakurikuler membaca pada siswa sekolah dasar di Qatar. Metodologi umum dari penelitian ini menerapkan metode triangulasi untuk mengumpulkan dan menganalisis data. Program tersebut dilakukan dalam bahasa Inggris dan Arab selama dua bulan yang terdiri dari 248 siswa kelompok perlakuan dan 176 siswa dalam kelompok kontrol. Hasil penelitian menunjukkan bahwa siswa yang bergabung dalam kegiatan ekstrakurikuler mengalami peningkatan minat baca meskipun pada awalnya nilai rata-rata sikap membaca dari kelas perlakuan lebih rendah dari pada kelas kontrol sebelum mendaftarkan diri dalam program membaca.

Selain menumbuhkan minat membaca, perlu menumbuhkan keterampilan menulis sejak dini. Dalam hal ini kegiatan menulis dapat dilakukan dengan menulis berbagai jenis karangan sesuai kompetensinya. Hal ini didukung oleh Prayoga, Suwignyo, \& Harsiati (2017) memberikan pendapat bahwa keterampilan menulis cerita narasi pada siswa dapat ditingkatkan dengan berbantuan buku cerita anak. Melalui buku cerita anak, siswa mampu berpikir kreatif untuk menghasilkan sebuah karya. Hal ini juga didukung oleh pendapat Jannah, Suwignyo, \& Harsiati (2019) yang menyatakan bahwa menulis kreatif merupakan sebuah kegiatan menceritakan peristiwa yang pernah dialami dengan memanfaatkan imajinasi kemudian dituangkan dalam sebuah tulisan. Kegiatan menulis dapat membuat siswa merasa senang jika menggunakan topik yang berbeda setiap waktu pertemuan

Berdasarkan paparan di atas, dari hasil studi pendahuluan, peneliti memperoleh hasil menarik di SD Muhammadiyah 4 kota Surabaya yaitu sekolah yang berakreditasi A ini menghasilkan kelompok siswa yang memiliki prestasi bidang akademik dan non akademik tingkat Nasional dan Internasional. Keberhasilan akademik berhubungan dengan kegiatan literasi. Alasan tersebut didukung oleh Retariandalas (2018) bahwasanya jika kegiatan membaca dilakukan secara rutin maka hal ini tidak hanya untuk menambah ilmu pengetahuan saja, tetapi juga memperkuat, memperdalam dan menyimpan ilmu yang telah diperolehnya sehingga prestasi belajar siswa akan meningkat. Prestasi akademik siswa berbasis kegiatan literasi adalah juara I lomba Bahasa Inggris tertulis LIPI Nasional, Juara I Lomba Story Telling-Piala Gubernur, dan juara satu Musikalisasi Puisi tingkat Provinsi. Kegiatan literasi juga didorong oleh komunitas sekolah yang telah menerapkan budaya literasi yang ditunjukkan di majalah sekolah dan peyelenggaraan berbagai program bernuansa literasi. Selain itu, sekolah telah memiliki berbagai sarana dan prasarana yang mendukung kegiatan literasi. Sekolah juga memiliki ekosistem literat yakni tidak hanya siswa yang bergerak dalam kegiatan literasi, namun para pendidik dan tenaga kependidikan juga berkontribusi dalam aktivitas literasi, seperti menuliskan materi pada majalah sekolah dan menulis buku.

Ketercapaian indikator gerakan literasi sekolah juga didorong oleh sarana dan prasarana yang relevan. Sekolah juga dilengkapi perpustakaan yang memiliki manajemen visi dan misi yang baik serta dilengkapi dengan kumpulan bahan bacaan, panggung kreatif, dan pojok browsing yang mendukung tercapainya tujuan Gerakan Literasi Sekolah. Pada tahun 2018, SD Mudipat meraih juara 1 Lomba Perpustakaan Tingkat Kota Surabaya yang diselenggarakan oleh Dinas Perpustakaan dan Kearsipan Kota Surabaya. Penilaian kejuaraan terdiri dari keadministrasian, kelengkapan dokumen-dokumen, desain dan 
kelayakan ruang perpustakaan, jumlah koleksi buku yang dimiliki, program-programnya serta aspek-aspek lainnya. Penelitian sebelumnya tentang implementasi GLS menjelaskan pelaksanaannya memiliki aspek yang berbeda. Lebih lanjut, implementasi Gerakan Literasi Sekolah juga dipengaruhi oleh bentuk pelibatan publik, faktor penghambat dan faktor pendukung yang berasal dari dalam maupun luar pihak sekolah serta upaya yang dilakukan untuk mengatasinya (Yulianto, Jannah, \& Nurhidayah, 2017); (Hidayat, Basuki, \& Akbar, 2018); (Khotimah, Akbar, \& Sa'dijah, 2018)). Hal ini dapat dijadikan sebagai bahan referensi sekolah dalam merencanakan program yang berkaitan dengan kegiatan literasi sehingga tujuan yang telah direncanakan akan berjalan sesuai rencana.

Peneliti tertarik untuk melakukan studi mendalam tentang pelaksanaan gerakan literasi sekolah di SD Muhammadiyah 4 Kota Surabaya. Kegiatan penelitian mengkaji pelaksanaan Gerakan Literasi Sekolah dalam kegiatan pembiasaan, pengembangan dan pembelajaran serta kendala yang termuat dalam kegiatan tersebut.

\section{METODE}

Penelitian menggunakan rancangan penelitian deskriptif kualitatif dengan jenis penelitian studi kasus yaitu peneliti turun langsung ke lapangan dengan tidak memberikan perlakuan apapun terhadap subjek dan kondisi lapangan yang diteliti. Sebelum mengadakan penelitian, peneliti melakukan observasi pendahuluan ke sebelas sekolah dasar di Kabupaten Trenggalek dan Surabaya.

Data yang digunakan dalam penelitian ini adalah kata-kata, tindakan, sumber tertulis atau dokumen. Data tersebut berasal dari sumber data meliputi kepala sekolah, wali kelas, kepala dan staf perpustakaan, pembina program pendukung Gerakan Literasi Sekolah, siswa dan orangtua. Pengumpulan data dilakukan dengan teknik wawancara, observasi, dan studi dokumentasi yang dianalisis secara berurutan melalui reduksi data, penyajian data, dan penarikan kesimpulan. Pengecekan keabsahan data dan temuan penelitian dilakukan dengan triangulasi.

\section{HASIL DAN PEMBAHASAN}

\section{Pelaksanaan Gerakan Literasi Sekolah}

Dari hasil penelitian menunjukan bahwa dalam pelaksanaan gerakan literasi sekolah mencakup tahap pembiasaan, pengembangan, dan pembelajaran. Tahap pembiasaan, meliputi (1) kegiatan literasi, (2) penyediaan sarana dan prasarana, (3) pengadaan lingkungan kaya teks dan (4) pelibatan publik. Tahap pengembangan, meliputi (1) kebiasaan kegiatan literasi, (2) program pendukung kegiatan literasi, (3) partisipasi pendidik dan staff dalam kegiatan literasi, (4) tim literasi sekolah dan (5) pengembangan profesional literasi bagi pendidik dan tenaga kependidikan sekolah. Tahap pembelajaran, meliputi (1) penggunaan buku pengayaan, (2) pemilihan buku teks pelajaran, (3) kegiatan menanggapi teks bacaan, dan (4) pemanfaatan sarana dan prasarana dalam pembelajaran.

\section{Pembiasaan Gerakan Literasi Sekolah}

Berkaitan dengan kegiatan literasi, pemimpin sekolah periode 2014/2018 memberikan kebijakan semua kelas untuk melakukan pembiasaan membaca yang dilakukan setiap hari di dalam kelas sebelum kegiatan pembelajaran. Kegiatan membaca bermacam buku fiksi maupun nonfiksi dilengkapi dengan kegiatan menuliskan kembali hasil pemahamannya pada buku literasi. Pendidik dan staf juga melakukan kegiatan literasi dengan menuliskan materi berdasarkan content pada majalah. Sekolah telah memiliki pergantian kepala sekolah untuk periode 2018/2022. Kepala sekolah periode ini memberikan kebijakan yang berbeda tentang kegiatan literasi bahwa pembiasaan literasi dilakukan secara fleksibel yaitu kegiatan membaca buku fiksi dilakukan atas panduan wali kelas yang bisa dilakukan kapan saja yakni di awal, tengah atau mendekati akhir pembelajaran. Peneliti juga melakukan observasi untuk mengetahui implementasi kegiatan literasi di dalam kelas. Pembiasaan membaca di dalam kelas tidak dilakukan secara serentak dengan beberapa alasan diantaranya adalah pembiasaan membaca juga dapat dilakukan melalui kegiatan Kunjungan Wajib Baca dan waktu luang baik di kelas maupun ketika menunggu orangtua di perpustakaan sekolah.

Berkaitan dengan pembiasaan kegiatan literasi dapat diketahui terdapat perubahan tentang waktu pelaksanaannya. Hendaknya pemimpin sekolah memberikan kebijakan tentang pelaksanaan pembiasaan membaca pada hari tertentu meskipun tidak dilakukan setiap hari. Hal tersebut bertujuan agar semua warga sekolah melakukan kegiatan secara konsisten dan semua warga sekolah memiliki pemikiran akan pentingnya membiasakan membaca siswa dari usia dini. Pertimbangan tersebut didukung dengan pendapat Antoro (2017) mengatakan bahwa kesadaran berliterasi yang dilakukan oleh pihak sekolah akan muncul jika dikendalikan oleh kepala sekolah. Pemimpin sekolah harus tetap memberikan kebijakan pada wali kelas untuk tetap membiasakan siswa membaca secara terjadwal karena minat baca siswa akan muncul jika kegiatan dilakukan secara berulang.

Selain pembiasaan literasi baca, sekolah juga menggalakan literasi menulis yang dilakukan setiap hari Kamis. "Kamis Menulis" merupakan kegiatan menulis kreatif yang meliputi cerita pendek, puisi, pantun dan lain sebagainya berdasarkan variasi topik dan tema dari wali kelas. Siswa dilatih untuk menulis dari pengamatan dan imajinasi. Wali kelas membimbing menulis dengan memberikan pertanyaan kemudian siswa menuangkan jawabannya ke dalam bentuk tulisan. Kegiatan ini dapat menumbuhkan kesenangan siswa dalam menulis karena dengan menulis siswa bisa menyampaikan ide, perasaan, dan emosi bukan menyampaikan informasi saja. Sejalan dengan pendapat ini, Sil.org (dalam USAID, 2014) menyatakan bahwa "Creative writing is writing that expresses the writer's thoughts and feelings in an imaginative, often unique, and poetic way” yang 
menjelaskan bahwa menulis kreatif adalah tulisan yang berisi buah pikiran dan perasaan menulis dengan menggunakan imajinasinya, unik, dan ditulis secara puitis. Pernyataan ini didukung juga dengan Abidin, dkk. (2018) yang menyatakan bahwa kemampuan melahirkan ide, produk, maupun proses akan membentuk kebiasaan pada siswa. Dari elemen tersebut, berpikir kreatif dikatakan sebagai keterampilan berpikir yang menghasilkan sesuatu yang baru dan bersifat inovatif.

Penyediaan sarana dan prasarana juga mendukung pembiasaaan membaca. Sarana literasi di sekolah meliputi (a) perpustakaan sekolah dan (b) perpustakaan kelas. Perpustakaan sekolah, meliputi (1) ruang perpustakaan (2) pengelola perpustakaan; (3) koleksi buku; (4) perlengkapan; (5) administrasi perpustakaan; (6) tata tertib. Luas ruangan perpustakaan sekolah yang telah diberikan nama Dauzan Library adalah $131 \mathrm{~m}^{2}$ dan terletak terpisah dengan gedung pembelajaran yakni berada pada gedung The Milleniunm Building yang memiliki visi dan misi yang sesuai dengan program Gerakan Literasi Sekolah yang telah diterapkan di sekolah. Perpustakaan sekolah harus terletak strategis dengan keberadaan kelas di lingkungan sekolah. Hal ini bertujuan agar komunitas sekolah, yaitu para pendidik dan siswa mudah menjangkaunya yang bertujuan pula memberikan motivasi para komunitas agar berkeinginan datang dan memanfaatkannya kapanpun (Yusuf \& Suhendar, 2007).

Ruangan telah dikelola oleh tenaga perpustakaan yang memiliki kualifikasi pendidikan akhir sarjana. Kedua pengelola yang terdiri dari kepala dan staf perpustakaan memperoleh kepercayaan dari kepala sekolah untuk menjaga kondisi ruangan dan administrasi perpustakaan. Dengan adanya pengelolaan yang baik maka kegiatan di perpustakaan akan berjalan efisien dan efektif. Hal ini sejalan dengan Bernard (dalam Widiasa, 2007) yang memaparkan bahwa sebuah organisasi yang melakukan kerjasama dilakukan oleh dua orang atau lebih dalam melaksanakan tugasnya.

Ruangan ini tidak menyediakan buku teks pembelajaran, tetapi menyediakan koleksi buku fiksi dan nonfiksi yang memiliki perbandingan jumlah 60:40 yang diperhatikan pergantiannya setiap tahun. Maksud dari perbandingan ini adalah 60\% meliputi jenis koleksi yang tergolong fiksi dan 40\% mencakup kategori buku nonfiksi (Yusuf \& Suhendar, 2007). Di samping itu, Bafadal (2011) menyatakan bahwa guru/pustakawan harus selalu mendapatkan tambahan buku, baik dengan cara membeli, pinjam, atau tukar menukar antar perpustakaan sekolah. Pengadaan buku dilakukan dengan pembelian, hadiah atau sumbangan, dan swadaya masyarakat setempat. Untuk pembelian buku, perpustakaan memperoleh alokasi dana sekitar 50 - 60 juta setiap tahunnya. Orangtua atau ikatan wali murid juga berkontribusi dengan mengumpulkan buku setiap akhir semester ketika pengambilan raport. Begitu pula, sebuah instansi juga membantu perpustakaan dalam meningkatkan kuantitasi buku.

Macam perlengkapan yang disediakan, meliputi papan pengumuman, tempat penitipan barang, bermacam rak buku, meja dan kursi, komputer, dan ruang presentasi. Penataan bermacam pelengkapan disesuaikan dengan luas ruangan perpustakaan dengan rapi dan strategis sehingga aktivitas literasi siswa tidak terganggu dan memperoleh kenyamanan. Hal ini sesuai dengan pernyataan Bafadal (2011) bahwa meja dan kursi di perpustakaan harus ditata dengan sebaik-baiknya agar siswa dapat belajar dengan nyaman, aman, dan tenang.

Pengelola perpustakaan juga melakukan administrasi perpustakaan dengan mereview daftar peminjaman, koleksi buku, menyediakan kartu anggota. Perpustakaan yang memberikan layanan membaca setiap hari yaitu hari Senin sampai Jum'at yang dimulai pukul 07.15-16.30 WIB tersebut juga memberikan tata tertib untuk diperhatikan oleh siswa yang disajikan pada papan dan sepotong kertas pada semua buku. Hal ini sesuai dengan fungsi perpustakaan menurut Bafadal (2011), yaitu (1) edukatif; (2) informatif; (3) tanggung jawab administratif; (4) riset; (5) rekreatif. Fungsi edukatif, dengan menyediakan berbagai macam buku, baik buku fiksi maupun nonfiksi yang telah dikelompokkan sehingga siswa dapat memperoleh dan mencarinya tanpa bimbingan guru atau tenaga perpustakaan baik secara individual maupun kelompok sehingga perpustakaan dapat menunjang penyelenggaraan pendidikan di sekolah. Fungsi informatif, selain menyediakan berbagai bahan pustaka, perpustakaan juga media yang berfungsi memberikan informasi utuk siswa, seperti komputer yang diletakkan di pojok browsing. Fungsi tanggung jawab dan administratif, terdapat berbagai macam layanan yan yang harus dilakukan oleh pengelola perpustakaan dan peraturan yang harus dipatuhi oleh siswa yang bertujuan untuk mendidik siswa memiliki sikap tanggung jawab. Fungsi rekreatif, ruangan telah memberikan layanan siswa sebagai tempat untuk dikunjungi.

Sudut baca, meliputi (1) penataan sudut baca, (2) pengelolaan sudut baca, dan (3) koleksi sudut baca. Semua kelas telah memiliki perpustakaan kelas atau sudut baca berupa lemari dengan bentuk dan ukuran sama. Penataan lemari pada semua kelas dilakukan dengan hal sama yaitu berada di pojok depan kelas yang bertujuan selalu dalam pandangan siswa. Setiap kelas memiliki jenis buku berbeda yang disesuaikan dengan jenjang kelasnya. Pengelolaan perpustakaan kelas juga dilengkapi dengan buku induk yang berisi tentang pendataan macam buku dan buku layanan perpustakaan berisi daftar nama peminjam buku serta waktu untuk mengembalikannya. Selain itu, koleksi sudut baca, seperti buku fiksi dan nonfiksi serta jurnal literasi siswa juga dikelompokkan sesuai jenisnya agar mudah dalam mencarinya. Temuan tersebut sesuai dengan pendapat Gipayana (2011) yang mengemukakan bahwa sudut baca perlu ditata dengan baik agar menarik siswa untuk memanfaatkannya yaitu dengan memajang buku-buku dalam rak yang sesuai dengan kondisi kelas serta tetap memperhatikan keindahan dalam penataan tersebut.

Sekolah juga mengadakan lingkungan kaya teks, meliputi (1) mading kelas, (2) mading sekolah, dan (3) pajangan. Setiap kelas memiliki dua macam mading, yaitu mading akademik berupa daftar anggota kelas, daftar piket, dan daftar pelajaran, sedangkan mading kreativitas siswa mencakup hasil karya kurikuler maupun non kurikuler. Temuan lain di kelas adalah terdapat pajangan hasil karya siswa baik dalam bentuk teks maupun gambar yang ditempelkan dan digantung pada dinding dan jendela kelas. Hal ini bertujuan untuk memotivasi siswa agar memiliki minat literasi dan meningkat sesuai jenjang kelasnya. Senada dengan hal ini, Dewayani (2017) menjelaskan bahwa minat literasi membaca pada anak dapat ditumbuhkan 
dengan membuat ruang kelas semarak dengan teks bacaan. Mading sekolah terletak pada setiap lantai pada gedung pembelajaran dengan bahan ruang kaca terdiri dari beberapa topik yaitu information, achievement, extracurricular dan student's creations. Sekolah juga menampilkan pajangan dalam bentuk poster maupun baliho yang berisi tentang prestasi akademik maupun nonakademik siswa dan pendidik sekolah. Kondisi di lapangan sesuai dengan Kraus \& Boss (dalam Abidin, 2015) yang mengartikan pajangan adalah sebuah tempat untuk menempelkan pekerjaan siswa baik pekerjaan lama maupun yang baru sebagai alur dan kemajuan belajar yang dicapainya.

Pelibatan publik meliputi (1) orangtua siswa, (2) penerbit buku, (3) pegiat literasi, dan (4) instansi. Bentuk kontribusi dari orangtua, meliputi pengadaan bahan bacaan dan renovasi lemari buku untuk perpustakaan sekolah dan kelas. Penerbit berkontribusi dalam bentuk jasa yakni menyediakan bazar buku ketika semester akhir yang bertujuan agar orangtua memperoleh kemudahan dalam pembelian buku yang akan disumbangkan. Pegiat literasi yakni penggagas dan konsultan Literasi Nasional juga memberikan perhatian dan dukungan dalam aktivitas literasi komunitas sekolah dengan memberikan materi pada workshop literasi di aula sekolah dan memberikan dukungan dalam bentuk tulisan yang disajikan pada bagian pendahuluan antologi berita sekolah "Gila Nulis Berita Sekolah" Mudipat dan opini tentang membangun minat dan kemampuan membaca siswa pada majalah sekolah. Tidak jauh berbeda dengan kontribusi orangtua, sebuah instansi juga mengadakan sumbangan dalam bentuk bahan bacaan untuk perpustakaan sekolah. Peran serta komite sekolah, orangtua, alumni, dan dunia bisnis dan industri dapat mendukung dalam menjaga dan mengembangkan sarana sekolah agar capaian literasi siswa dapat terus ditingkatkan (Kemendikbud, 2016). Atmazaki, dkk. (2017) juga menyatakan bahwa peran fasilitator literasi yang berasal dari ranah keluarga, sekolah serta masyarakat tersebut sangat strategis sebagai upaya dalam meningkatkan budaya literasi.

\section{Pengembangan Gerakan Literasi Sekolah}

Pengembangan dalam gerakan literasi sekolah, meliputi (1) kebiasaan kegiatan literasi; (2) program pendukung kegiatan literasi; (3) partisipasi pendidik dan tenaga kependidikan dalam kegiatan literasi; (4) tim literasi sekolah; (5) pengembangan profesional berbasis literasi.

Berkaitan dengan kebiasaan kegiatan literasi siswa dapat dilihat dari kegiatan membaca atas inisiatif sendiri dan di luar rancangan program sekolah. Kegiatan membaca tidak hanya dilakukan sebelum pembelajaran di dalam kelas, namun minat baca siswa sudah ditunjukkan dengan meluangkan waktu membaca kapan saja dan di tempat yang mendukung aktivitas tersebut. Kebiasaan membaca dilakukan di dalam kelas karena sekolah telah menyediakan perpustakaan kelas sehingga aktivitas membaca dapat dilakukan kapan saja. Berdasarkan hasil observasi, minat membaca telah dimiliki oleh siswa di jenjang kelas yang dibuktikan dengan adanya keinginan siswa untuk membaca dari pada melakukan aktivitas lain. Mayoritas siswa meluangkan waktu untuk membaca buku fiksi maupun nonfiksi ketika menunggu wali kelas dan bel masuk, ketika wali kelas atau pendidik menjelaskan materi pembelajaran dan ketika waktu istirahat. Siswa dapat membaca berbagai bahan bacaan dari perpustakaan kelas, perpustakaan sekolah atau buku dari rumah. Kebiasaan membaca di luar kelas dilakukan di sekitar kelas dan di perpustakan sekolah. Perpustakaan sekolah selalu memperoleh pengunjung dari semua jenjang kelas kapan saja karena ruangan tersebut selalu membuka layanan membaca dari pukul 07.15-16.30. Berkaitan dengan hal ini, Wijesuriya (dalam Chettri \& Rout, 2013) menyatakan bahwa kegiatan membaca dianggap sebagai kebiasaan ketika berulang kali dilakukan, yakni berdasarkan jumlah bahan yang dibaca dan frekuensi membaca sebagai rata waktu yang dihabiskan untuk membaca.

Selain kegiatan literasi tulis di dalam kelas, siswa juga melakukan kegiatan literasi tulis melalui media yang disediakan sekolah yaitu majalah sekolah. Majalah sekolah memberikan kesempatan siswa untuk mengumpulkan hasil karya tulisnya ke staff redaksi majalah atau alamat online situs sekolah. Siswa dapat menulis karangan dalam bentuk surat pembaca, pantun dan puisi, lukisan, cerita pendek dan mengenalkan pribadinya pada bagian cita-citaku. Tidak hanya disajikan dalam majalah sekolah, sekolah telah mengumpulkan karya siswa dalam bentuk buku. Siswa pada jenjang kelas III sampai kelas VI juga telah menghasilkan karya dalam bentuk teks narasi yang telah dibukukan dari tahun 2013 sampai sekarang. The Fantasy Land merupakan antologi cerpen karya siswa-siswi yang berisi tentang cerita pendek yang telah dicetak oleh penerbit pada tahun 2013. Seiring berjalannya waktu, pada April tahun 2015 merupakan awal sekolah menerbitkan sendiri karya siswa yang berjudul Cicak di Balik Handuk, Dunia Ceriaku, 14 Hari yang Mengasyikkan dan Ramuan Ajaib. Yang lebih menarik adalah buku yang berjudul "Ramuan Ajaib" merupakan hasil karya siswa kelas IIID yang berisi hasil menulis siswa dari Kamis Menulis. Hal demikian merupakan bukti dari hasil belajar siswa yang dikumpulkan dalam bentuk portofolio. Menurut DeFina (dalam USAID, 2014) portofolio adalah kumpulan hasil pekerjaan siswa yang bermakna yang dikumpulkan berdasarkan periode waktu tertentu. Sekolah juga memiliki program yang mendukung kegiatan literasi, seperti (1) ekstrakurikuler menulis; (2) wartawan kecil; (3) peringatan hari besar nuansa literasi.

Ekstrakrikuler menulis dilakukan setiap hari Rabu di ruang kelas pada gedung pembelajaran. Melalui kegiatan ini, siswa tidak hanya menulis saja namun pembina juga memberikan materi tentang komponen dalam cerita yang harus diperhatikan seperti susunan kalimat, gaya dalam kalimat dan tanda baca. Kegiatan ekstrakurikuler juga didukung motivasi ekstrinsik, salah satu nya melalui Mudipat Writing Camp di sebuah hotel Surabaya. Editor media kabar juga menjelaskan berbagai cara untuk mengembangkan ide yang harus memperhatikan pula alur cerita yang telah ditulis. Pembimbing eskul menulis juga mengajak siswa bergabung dalam acara peluncuran dan diskusi serial novel anak karya Okky Madasari di sebuah tempat umum. 
Selain ekstrakurikuler diatas, wartawan cilik atau warcil merupakan ekstrakurikuler yang diikuti oleh siswa kelas tinggi yang dimulai pada tahun 2003. Pembina kegiatan memberikan materi untuk siswa secara reguler dengan berpartisipasi dalam mengumpulkan berita ketika mendapat kunjungan dari tamu yang berperan serta dalam kegiatan belajar di sekolah. Warcil tidak hanya bergerak aktif di dalam sekolah saja namun juga memperoleh kesempatan dalam kegiatan di luar sekolah dengan bergabung bersama wartawan kelas dewasa dari instansi dan sekolah. Kegiatan wawancara juga dilakukan dengan para tamu yang bergerak dalam segala bidang baik bidang pendidikan, pemerintahan maupun sosial politik. Aktivitas warcil tidak hanya bergelut dalam mencari informasi saja, namun siswa juga berlatih menuliskan hasil wawancaranya pada majalah sekolah.

Sekolah juga menunjukkan kesungguhan dalam mengembangkan kegiatan literasi dengan mengadakan perlombaan untuk memperingati Hari Besar Nasional, seperti Bulan Bahasa, Milad Mudipat, Milad Muhammadiyah, dan Hari Kartini. Semua siswa yaitu kelas tinggi maupun kelas rendah dapat mengikuti lomba tersebut tanpa ada persyaratan khusus. Kegiatan ini bertujuan untuk memotivasi siswa agar minat baca dan tulis siswa berkembang sesuai dengan progres gerakan literasi. Berkaitan dengan ketiga program tersebut, Abidin, dkk. (2018) menyatakan bahwa program sekolah tidak harus bersifat spektakuler, melainkan cukup program yang membentuk kebiasaan dan budaya siswa dalam membaca, menulis, dan berbicara dalam multikonteks dan multibudaya. Program sekolah harus bersifat berkelanjutan, fleksibel, dan komprehensif.

Pendidik dan tenaga kependidikan sekolah juga berpartisipasi dalam kegiatan literasi dengan menulis materi berdasarkan topik pada majalah sekolah. Selain itu, pendidik dan staf juga menghasilkan produk dalam bentuk buku dan klipping. Peran serta pendidik dan tenaga kependidikan dalam kegiatan literasi sangat penting karena dapat memberikan motivasi siswa untuk lebih bergerak aktif dalam kegiatan literasi khususnya ekosistem sekolah literat.

Sekolah juga mendukung dalam pengembangan profesional literasi melalui pendampingan pelatihan berbasis kegiatan literasi. Kegiatan ini dilakukan dengan memberikan pengetahuan bermuatan program dengan topik dan praktik literasi yang efektif dan tepat. Sekolah telah mengikutsertakan beberapa pendidik dan tenaga kependidikan dalam pelatihan literasi di sekolah maupun instansi lain. Sekolah juga mengadakan workshop literasi di aula sekolah dengan mengundang pegiat literasi Nasional yang memberikan materi tentang pelaksanaan dan pengelolaan program literasi di lapangan. Kegiatan ini menunjukkan adanya keinginan sekolah dalam mewujudkan budaya literasi di sekolah dengan memiliki ekosistem literat. Pendampingan terhadap pelatihan dapat dilaksanakan secara langsung bersama dengan para guru/pendidik/pegiat dalam bentuk pertemuan individu dan kelompok kecil (Atmazaki, dkk., 2017). Hal tersebut juga didukung oleh pernyataan Kimmy, dkk (2017) bahwa "teacher must be knowledgeable of the components of literacy in order to effectivelly teach the skill to their student". Hal ini menyatakan bahwa pendidik harus memiliki pengetahuan tentang komponen literasi agar kegiatan pengajaran siswa berjalan secara efektif. Dengan adanya pendampingan profesional berbasis literasi, pendidik dapat mengembangkan kompetensi dan pengetahuannya yang bermanfaat juga dalam pembelajaran pada bidang literasi khususnya.

Meskipun adanya pelatihan berbasis literasi dan komunitas sekolah yang bergerak aktif dalam literasi, sekolah tidak memiliki Tim Literasi Sekolah. Pemimpin sekolah telah menganggap semua pendidik dan tenaga kependidikan bekerjasama secara aktif dalam kegiatan literasi sehingga tidak ada pengakuan keberadaan Tim Literasi Sekolah. Cobb (dalam Beers, dkk., 2010) berpendapat bahwa kepala sekolah memiliki peran yang sangat penting dalam pembentukan Tim Literasi Sekolah. Dengan adanya Tim Literasi Sekolah, sekolah dapat melakukan kreativitas dan inovasi serta koordinasi dengan pihak internal maupun eksternal dalam mengembangkan program bernuansa literasi.

\section{Pembelajaran Gerakan Literasi Sekolah}

Pembelajaran dalam Gerakan Literasi Sekolah, meliputi (1) penggunaan buku pengayaan, (2) pemilihan buku teks pembelajaran; (3) kegiatan menanggapi teks; (4) pemanfaatan sarana dan prasarana dalam kegiatan pembelajaran.

Penggunaan buku pengayaan dilakukan oleh mayoritas kelas dalam kegiatan pembelajaran yang diperoleh siswa dari pepustakaan kelas dan perpustakaan sekolah yang lebih banyak menyediakan bermacam buku referensi. Pemerolehan buku pengayaan tersebut disesuaikan dengan tema atau topik pembelajaran. Hal ini sesuai dengan Kemendikbud (2016) yang menyatakan bahwa elemen yang harus diperhatikan dalam memilih buku pengayaan untuk mendukung pembelajaran yaitu buku pengayaan harus sesuai dengan tema atau subtema materi ajar serta tujuan pembelajaran.

Sekolah memiliki wewenang dalam menggunakan berbagai sumber pembelajaran dalam kegiatan pembelajaran. Pihak sekolah khususnya pendidik lebih memilih menggunakan buku teks yang diterbitkan oleh swasta daripada kemendikbud karena: (1) memiliki tema terpadu dengan buku kemendikbud; (2) kegiatan pembelajaran pada buku teks swasta dapat membuat siswa lebih aktif daripada pada buku kementerian; (3) materi pembelajaran lebih detail; (4) menggunakan pendekatan saintifik 5M (Mengamati, Menanya, Mencoba, Menalar, dan Mengomunikasikan). Selain buku pendukung, semua siswa juga mendapatkan penambahan materi berupa rangkuman subtema pembelajaran. Rangkuman materi disajikan dalam lembaran kertas yang dibagikan oleh wali kelas dan kemudian ditempelkan pada buku tulis siswa. Selain memberikan tambahan materi, kegiatan pembelajaran akan berjalan efektif karena siswa langsung membaca materi dan mengerjakan pada lembaran. Hal ini sesuai dengan pasal 5 tahun 2016, Permendikbud RI memberikan pernyataan bahwa penerbitan buku teks pelajaran dapat dilakukan oleh Kementerian atau swasta. Kriteria atas kelayakan buku teks pelajaran yang diterbitkan oleh swasta dapat dilakukan penilaian oleh Badan Standar Nasional Pendidikan (BSNP) atau Tim Penilai yang ditetapkan oleh Menteri Pendidikan dan Kebudayaan sehingga dalam kegiatan pembelajaran, pendidik juga dapat menggunakan buku teks yang diterbitkan oleh kedua penerbit tersebut. 
Pemahaman literasi dalam pembelajaran dapat diketahui melalui kegiatan menanggapi teks yang dilakukan dengan cara berbeda yakni secara lisan dan tulis. Teks disajikan melalui beragam media baik cetak maupun audio yang dapat mendukung kegiatan literasi siswa. Menanggapi secara tulis dilakukan siswa dengan menjawab pertanyaan pada buku tulisnya. Selain itu, siswa juga menuliskan kembali isi cerita dari video pembelajaran juga dilakukan berdasarkan panduan wali kelas. Siswa juga dilatih untuk menanggapi teks secara lisan yang dapat ditemukan pada kegiatan pembelajaran dengan meminta siswa mengkomunikasikan hasil pemahamannya di depan kelas. Hal ini didukung dengan hasil penelitian Nurdiyanti \& Suryanto (2007) bahwa guru dapat menggunakan pendekatan komunikatif dan terpadu yang bertujuan untuk mencapai pembelajaran yang aktif, inovatif, kreatif, dan menyenangkan serta mencapai kompetensi siswa yang tercamtum dalam tujuan pembelajaran.

Kegiatan pembelajaran juga memerlukan bermacam buku yang disediakan pada perpustakaan sekolah dan kelas. Selain itu, siswa juga melakukan kegiatan pembelajaran di literacy corner pada lantai lima gedung pembelajaran. Kemendikbud (2016) menyatakan bahwa pemanfaatan perpustakaan dan sudut baca sekolah bertujuan untuk meningkatkan kecakapan literasi perpustakaan (library literacy) untuk siswa. Kecakapan literasi di perpustakaan, meliputi (a) pengetahuan tentang fungsi perpustakaan sebagai sumber pengetahuan dan koleksi informasi yang bermanfaat dan menghibur; (b) kemampuan memilih bahan pustaka yang sesuai jenjang dan minat secara mandiri; (c) pengetahuan tentang bahan pustaka sebagai produk karya penulisan yang diciptakan melalui proses kreatif; (e) pengetahuan tentang etika meminjam bahan pustaka dan berkegiatan di perpustakaan alternatif.

\section{Kendala dalam Pelaksanaan Gerakan Literasi Sekolah}

Kendala yang ditemukan dalam pelaksanaan Gerakan Literasi Sekolah, meliputi (1) masalah waktu dalam pelaksanaan kegiatan literasi, (2) berkurangnya bahan koleksi di dalam kelas pada akhir semester, dan (3) berkurangnya komitmen guru dalam melaksanakan pembiasaan membaca di kelas.

Pertama, pelaksanaan kegiatan literasi di sekolah memang dilakukan berdasarkan panduan dari wali kelas, namun dalam menumbuhkan minat membaca memerlukan waktu untuk membiasakan sehingga minat baca siswa akan ada dengan sendirinya. Sekolah harus memberikan keputusan tentang pelaksanan kegiatan wajib membaca di dalam kelas agar semua siswa melakukan kegiatan membaca pada hari tertentu. Dengan adanya kebijakan demikian, diharapkan pembiasaan membaca dilakukan oleh semua kelas. Kegiatan ini juga memberikan manfaat bahwa dengan pembiasaan membaca yang berjalan rutin akan menghasilkan minat membaca pada siswa sehingga keinginan membaca dengan sendirinya akan ada.

Kedua, masalah ketersediaan bahan koleksi baca di dalam kelas juga terjadi pada sekolah dalam akhir semester ganjil 2018/2019. Berkurangnya bahan koleksi di perpustakaan kelas dikarenakan adanya pengambilan buku untuk disumbangkan ke sekolah lainnya dan pada akhir semester tersebut kegiatan donasi buku dari wali kelas tidak ada karena pengambilan rapor dilakukan di luar sekolah melalui acara penggalian sumbangan untuk negara lain. Masalah ini bisa dikendalikan dengan adanya donasi buku yang dilakukan oleh orangtua siswa dalam pengambilan rapor pada semester selanjutnya.

Ketiga, berkurangnya komitmen guru dalam melaksanakan kegiatan pembiasaan membaca di kelas bersamaam dengan berubahnya kebijakan dari kepala sekolah atas pentingnya kegiatan literasi untuk warga sekolah khususnya kegiatan pembiasaan membaca. Dari masalah ini hendaknya kepala sekolah memberikan kebijakan tentang pelaksanaan pembiasaan membaca pada hari tertentu secara serentak sehingga warga sekolah yaitu wali kelas dan siswa memiliki motivasi dalam melaksanakan kegiatan tersebut. Sejalan dengan hal ini, Antoro (2017) menyatakan bahwa kesadaran berliterasi yang dilakukan oleh pihak sekolah akan muncul jika dikendalikan oleh kepala sekolah.

\section{SIMPULAN}

Kesimpulan hasil penelitian dan pembahasan pelaksanaan gerakan literasi sekolah dan kendalanya di SD Mudipat Kota Surabaya. Pembiasaan kegiatan literasi, meliputi (1) pembiasaan kegiatan literasi, (2) penyediaan sarana dan prasarana, (3) pengadaan lingkungan kaya teks, dan (4) pelibatan publik. Pertama, komunitas sekolah telah berperan aktif dalam kegiatan literasi sebelum adanya kebijakan Gerakan Literasi Sekolah pada tahun 2015. Pembiasaan literasi berjalan berdasarkan kebijakan dari Kepala sekolah. Kedua, kegiatan literasi juga didukung dengan penyediaan sarana dan prasana dengan pengelolaan yang baik yaitu perpustakaan sekolah dan perpustakaan kelas. Ketiga, sekolah juga mengadakan lingkungan kaya teks dengan menampilkan hasil karya siswa yang ditampilkan di mading kelas dan mading sekolah serta pajangan berbagai poster dan baliho di lingkungan sekolah. Keempat, pelibatan publik juga sangat diperlukan untuk mendukung kegiatan literasi di antaranya orangtua siswa, penerbit buku, pegiat literasi dan instansi dengan bantuan dalam bentuk materi dan jasa.

Pengembangan dalam pelaksanaan Gerakan Literasi Sekolah, meliputi (1) kebiasaan kegiatan literasi, (2) program pendukung kegiatan literasi, (3) partisipasi pendidik dan tenaga kependidikan dalam kegiatan literasi, (4) terbentuknya tim literasi sekolah, dan (5) pengembangan profesional literasi bagi pendidik dan tenaga kependidikan. Pertama, siswa telah memiliki kebiasaan membaca yang bisa dilakukan di dalam maupun di luar kelas dan kegiatan literasi tulis dilakukan dengan dengan mengumpulkan hasil menulisnya pada majalah sekolah dan buku karya siswa. Kedua, sekolah memilki program pendukung kegiatan literasi di luar kegiatan kurikuler, meliputi ekstrakurikuler menulis, wartawan cilik dan mengadakan peringatan hari besar nuansa literasi. Ketiga, pendidik dan tenaga kependidikan juga berpartisipasi dalam kegiatan literasi dengan menulis materi di majalah sekolah dan menulis buku cerita fiksi dan nonfiksi. Keempat, pendidik dan tenaga 
kependidikan juga memperoleh pendampingan pelatihan untuk mengembangkan profesional literasi dengan mengikuti pelatihan di luar sekolah dan workshop literasi yang diadakan sekolah tersebut. Kelima, sekolah tidak memiliki tim literasi yang dapat begerak aktif dalam kegiatan literasi.

Pembelajaran, kegiatan literasi dalam pembelajaran menggunakan buku pengayaan, pemilihan buku teks pembelajaran yang digunakan telah diterbitkan oleh penerbit swasta, kegiatan menanggapi teks dilakukan secara lisan dan tertulis, dan pemanfaatan sarana dan prasarana dalam kegiatan pembelajaran. Kendala dalam pelaksanaan Gerakan Literasi Sekolah, meliputi masalah waktu pelaksanaan kegiatan literasi, berkurangnya bahan koleksi baca di dalam kelas, dan berkurangnya komitmen guru dalam melaksanakan kegiatan pembiasaan membaca di kelas bersamaan dengan berubahnya kebijakan dari kepala sekolah atas pentingnya kegiatan literasi untuk warga sekolah.

Berdasarkan hasil penelitian di atas, dapat diajukan beberapa saran yang perlu diperhatikan oleh beberapa pihak untuk meningkatkan pelaksanaan gerakan literasi sekolah. Bagi kepala sekolah, hendaknya memberikan kebijakan tentang pelaksanaan pembiasaaan literasi membaca yang harus dilakukan pada hari tertentu agar siswa di semua kelas melaksanakan secara serentak kegiatan literasi. Kepala sekolah juga harus melakukan pengawasan dan evaluasi terhadap pelaksanaan Gerakan Literasi Sekolah dan kegiatan literasi siswa di dalam maupun di luar kelas yang dapat digunakan sebagai bahan evaluasi. Selain itu, keberadaan tim literasi sekolah hendaknya juga harus ada meskipun semua pendidik dan tenaga kependidikan telah berpartisipasi aktif dalam kegiatan literasi. Bagi pendidik, hendaknya tetap melaksanakan kegiatan literasi untuk siswa di dalam kelas meskipun tidak dilakukan setiap hari. Selain itu, hendaknya semua pendidik dan tenaga kependidikan sekolah memiliki perencanaan program kegiatan literasi yang disesuaikan dengan kompetensi di setiap jenjang kelasnya. Peneliti lain yang ingin melakukan penelitian, dapat mengembangkan penelitian dengan aspek yang mendukung Gerakan Literasi Sekolah. Seperti halnya kegiatan literasi secara khusus yang meliputi perencanaan, pelaksanaan, dan evaluasi program tersebut. Selain itu, dapat digunakan bahan rujukan tentang penelitian eksperimen yaitu pengaruh pelaksanaan gerakan literasi sekolah terhadap minat literasi siswa di sekolah dasar.

\section{DAFTAR RUJUKAN}

Abidin, Y. (2015). Pembelajaran Multiliterasi. Bandung: PT. Refika Aditama.

Abidin,Y., Mulyani, T., Yunansah, H. (2018). Pembelajaran Literasi-Strategi Meningkatkan Kemampuan Literasi Matematika, Sains, Membaca, dan Menulis. Jakarta: Bumi Aksara.

Antoro, B. (2017). Gerakan Literasi Sekolah. Dari Pucuk Hingga Akar. (Online) (https://doi.org/10.1017/S0033291700036606), Atmazaki, Ali, N. B. V., Muldian, W., Miftahussururi, Hanifah, N., Nento, M. N., Akbari, Q. S. (2017). Panduan Gerakan Literasi Nasional. Jakarta: Kementerian Pendidikan dan Kebudayaan.

Badan Pengembangan dan Pembinaan Bahasa. (2016). Pedoman Gerakan Nasional Literasi Bangsa-Menciptakan Ekosistem Sekolah dan Masyarakat Berbudaya Baca-Tulis serta Cinta Sastra. Kementerian Pendidikan dan Kebudayaan.

Bafadal, I. (2011). Pengelolaan Perpustakaan Sekolah. Jakarta: PT Bumi Aksara.

Beers, C. S., Beers, J. W \& Smith, O. J. (2010). A Principle's Guide to Literacy Instruction. London: The Guilford Press.

Chettri, K., \& Rout, S. K. (2013). Reading Habits - An Overview. IOSR Journal of Humanities And Social Science, (IOSR JHSS), 14(6), 13-17.

Dewayani, S. (2017). Menghidupkan Literasi di Ruang Kelas. Yogyakarta: PT Kanisius.

Gipayana, M. (2011). Sudut Baca, Pajangan, Partisipasi Orangtua Siswa dan Mutu Pembelajaran Membaca-Menulis di SD. Kajian Teori dan Praktik Pendidikan.

Hidayat, M., Basuki, I., \& Akbar, S. (2018). Gerakan literasi Sekolah Dasar. Jurnal Pendidikan: Teori, Penelitian, dan Pengembangan, 3(6), 810-817.

Jannah, E. M. N., Suwignyo, H., \& Harsiati, T. (2019). Analisis Nilai-nilai Karakter Hasil Karya Menulis Kreatif Siswa. Jurnal Pendidikan: Teori, Penelitian, dan Pengembangan, 4(20), 149-155.

Kemendikbud. (2016). Panduan Gerakan Literasi Sekolah di Sekolah Dasar. Jakarta: Direktorat Jenderal Pendidikan Dasar dan Menengah Kementerian Pendidikan dan Kebudayaan.

Khotimah, K., Akbar, S., \& Sa'dijah, C. (2018). Pelaksanaan Gerakan Literasi Sekolah. Jurnal Pendidikan: Teori, Penelitian, dan Pengembangan, 3(11), 1488-1498.

Lestari, L. A. (2017). Literasi Lintas Disiplin-Membangun Literasi Sekolah, Keluarga, Komunitas, untuk Kebangkitan Indonesia. Surabaya: Unesa University Press.

Mendikbud. 2016. Peraturan Menteri Pendidikan dan Kebudayaan Republik Indonesia No 08 Tahun 2016 - Buku yang digunakan oleh Satuan Pendidikan.

Nasser, R. (2013). A Literacy Exercise: An Extracurricular Reading Program as an Intervention to Enrich Student Reading Habits in Qatar. International Journal of Education and Literacy Studies, 1(1), 61-71.

Nurdiyanti \& Suryanto. (2010). Indonesia Pada Siswa Kelas V Sekolah Dasar, (1), 115-128.

Prayoga, R , Suwignyo, H., \& Harsiati, T. (2017). Peningkatan Keterampilan Menulis Cerita Berbantuan Media Buku Cerita Anak. Jurnal Pendidikan: Teori, Penelitian, dan Pengembangan, 2(11), 1498-1503.

Retariandalas, R. (2018). Pengaruh Minat Membaca dan Motivasi Belajar terhadap Prestasi Belajar IPA Siswa. Formatif: Jurnal Ilmiah Pendidikan MIPA, 7(2), 190-197. https://doi.org/10.30998/formatif.v7i2.1529 
Sutrianto., Rahmawan, N., Hadi, S., \& Fitriono, H. (2016). Panduan Gerakan Literasi Sekolah di Sekolah Menengah Atas. Jakarta: Direktorat Jenderal Pendidikan Dasar dan Menengah Kementerian Pendidikan Dasar dan Menengah.

Tarigan, H. G. (2008). Menulis sebagai Suatu Keterampilan Berbahasa. Bandung: Angkasa.

Unesco. (2003). The Prague Declaration “Towards An Information Literate Society.” Retrieved August 23, 2018, From Unesco. (Online), (http://www.unesco.org/fileadmin/multimedia/hq/ci/ci/pdf/praguedeclaration.pdf).

USAID. (2014). Prioritas Mengutamakan Pembaharuan, Inovasi, dan Kesempatan bagi Guru, Tenaga Kependidikan, dan Siswa. Jakarta: USAID LPTK.

Yulianto, B., Jannah, F., \& Nurhidayah. (2017). The Implementation of School Literacy Movement in Elementary School. Advances in Social Science, Education and Humanities Research, 173(Icei 2017), 43-46.

Yusuf, P \& Suhendar, Y. (2007). Pedoman Penyelenggaraan Perpustakaan Sekolah. Jakarta: Kencana Prenada Media Group. 